\title{
Land-cover change assessment in Ejisu -Juabeng district in Ghana
}

\author{
Edward D. Wiafe ${ }^{1 *}$, George Asamoah ${ }^{2}$ \\ 1) Department of Environmental and Natural Resources Management, Presbyterian University College, Ghana \\ 2) Department of Tourism Management, Marshall University College, Accra, Ghana \\ Corresponding Author: edward.wiafe@ presbyuniversity.edu.gh
}

\begin{abstract}
This study was conducted to analyse the changes in land-cover structure from 2002 to 2010 at a peri-urban district in Ghana namely Ejisu-Juabeng District. Satellite images were obtained from Landsat ETM+ for 2002 and compared to 2010 to identify the magnitude of change, causes for change and their impact on ecosystem services and human livelihood. The images were processed, classified and assessed for accuracy in ERDAS imagine version 2010. ArcGIS10 was used for GIS operations and Microsoft Excel software for statistical analysis. In addition, GPS (Garmin 12) was depended on for field routing and collection of ground truth data. Interviews were conducted in the communities to determine the causes of change and its impact on livelihoods. It was found that the about $74 \%$ of the forest cover has been changed to non-forest landuse types. The farmlands and fallow lands have increased to $53.6 \%$ and $103.67 \%$ respectively from 2002 to 2010 . However, grassland, marshy area and builtup/bare areas have reduced in sizes to $56.51 \%, 35.31 \%$ and $94.66 \%$ respectively. Recommendations for sustainable landuse management have been made.
\end{abstract}

Keywords: Land cover, Forest, sustainability, ecosystem services, livelihoods, Land use types.

Özet

$\mathrm{Bu}$ çalışma, Ejisu-Juabeng (Gana) kent çevresindeki arazi kullanımının 2002 ve 2010 yılları arasındaki değişimini ortaya koymayı hedeflemiştir. Uydu görüntüleri 2002 yılı için Landsat ETM+ uydusundan temin edilmiş ve 2010 yılı verileri ile karşılaştırılarak, değişimin miktar olarak büyüklüğü, nedenleri ve ekosistem hizmetleri ve insan yaşamına olan etkileri belirlenmiştir. Görüntüler ERDAS 10v.'de hassas bir veriye dönüştürülmek üzere işlenmiş, sınıflandırılmış ve değerlendirilmiştir. Coğrafi bilgi sistemi işlemleri için ArcGIS10 ve istatistik analizler için Excel programları kullanılmıştır. Ayrıca, arazi verisi toplamak ve doğrulama yapmak amacıyla GPS (Garmin 12) kullanılmıştır. Arazi kullanımındaki değişimin insan yaşamındaki etkilerini ortaya koymak için anketlere başvurulmuştur. Çalışma sonucunda, incelenen arazinin \% 74 'ünün orman alanından orman olmayan alana dönüştüğü tespit edilmiştir. Tarım alanları ve nadasa bırakılan alanların 2002 yılından 2010 yılına kadar sırasıyla \%53.6 ve 103.67 oranında arttığı görülmüştür. Bununla birlikte, çayır alanlarının, bataklık alanlarının ve sert yapı alanlarının sırasıyla \%56.51, 35.31 ve 94.66 oranında azaldığı ortaya çıkmıştır. Sürdürülebilir arazi kullanımı için önerilerde bulunulmuştur.

Anahtar kelimeler: Arazi örtüsü, Orman, sürdürülebilirlik, ekosistem hizmetleri, insan yaşamı, arazi kullanımı tipleri.

\section{Introduction}

Landscape structures in ecoregions have been undergoing through enormous changes as a result of forces ranging from fast population increase to urban extension. Patches are formed in landscapes when fractions of the vegetation cover are deleted and/or transformed to other covers, ultimately resultant in an everlasting land cover change. Land-cover is a witnessed physical cover, including natural or artificial vegetation and anthropological structures such as roads and railway networks, buildings, 
football fields and airports; that cover the earth's surface (Briassoulis, 2009). Though land-cover change occurs naturally, it is often augmented by connections between humans and environment. Consequently, land cover changes vary significantly from province to province and from locality to locality because of peculiar nature of interactions among the natural, community, economic , and political factors occurring at a particular locality (Antwi et al., 2014; Atuah \& Laing, 2001). Changing land cover patterns can best be understood and managed through periodic monitoring to arrive at current state of resources (Chen, 2002). Monitoring land cover change is essentially important because of the level of influence of this change on global climatic conditions and sea levels (Meyer \& Turner, 1992; Armah et al., 2011; Rainis, 2003). The effect of land cover change has been identified to be enormous on hydrological balance and biodiversity (Turner, 1989). However, most of the land-cover change studies occur at the global and landscape scales or national eco-regional level safe Tutu (2008) whose study occur in a typical rural landscape. A study on land-cover change is very critical in areas which used to be rural but gradually transforming to peri-urban and this paper serves the purpose i.e., provides scrutiny of transformations in land-cover structure from 2002 to 2010 at a community (district) level in Ghana. The specific objectives of this study were to identify the magnitudes of changes, reasons for changes and impact of land cover changes on ecosystem services and human livelihood.

\section{Materials and Methods}

\section{Study area}

The Ejisu-Juaben district is positioned in the middle sector of the Ashanti Region (Ghana) and is found within latitude $1.15^{\circ} \mathrm{N}$ and $1.45^{\circ} \mathrm{N}$ and longitude $6.15^{\circ} \mathrm{W}$ and $7.00^{\circ} \mathrm{W}$. The district expands over an area of $637.2 \mathrm{~km} 2$ (Figure 1). The vegetation in the district has been classified as semi-deciduous forest zone. The economy of the districts is an agricultural based which $68.2 \%$ of the people depended for a living. The main cash crops cultivated in the district are cocoa (Theobroma cacao), oil palm (Eleais guinensis) and citrus (Citrus spp.) while food crops like cassava (Manihott utilissima), maize (Zea mays), cocoyam (Colocasia esculenta) and tomatoes (Solanum lycopersicum ) are grown for home consumption and sell the surplus.. Human actions such as slash and burn agriculture, stone quarrying and chain-saw operations have led to squalor of the natural vegetation cover into secondary forest (Ministry of Food and Agriculture, 2011). These human activities have high tendency to affect the standards of local community members who rely more on resources of natural forest ecosystem (Benefo, 2008). The landscape is approximately level, with altitude ranging from $240 \mathrm{~m}$ to $300 \mathrm{~m}$ above sea level. The soil types developed from pre-cambrian rocks of the Birimian and Tarkwaian formations. The rainfall is bi-modal with the major rainy season starting from March to July and minor rainy season from September to November. The average annual rainfall is $1200 \mathrm{~mm}$ and average temperatures usually ranges between $20^{\circ} \mathrm{C}$ and $32^{\circ} \mathrm{C}$ in August and March respectively. (Ministry of Local Government, 2006). The area is mainly rural with an estimated number of people being 144,272 showing an increase in population in relation to previous years' and the youth forming $64 \%$ of the population (Ministry of Food and Agriculture, 2011).

\section{Method}

Landsat ETM+ image (04/02/2010, Level 1 B with path/ row 194/55) and Landsat ETM+ $(09 / 07 / 2002$, Level $1 \mathrm{~B}$ with path/ row 194/55) with not greater than $10 \%$ cloud cover was acquired and processed for the land cover mapping and change detection. A boundary shape file of the Ejisu-Juaben district, developed by the Ghana Lands Commission in 1991 was used in the creation of the image of the study area. The shape file was used to pin the Landsat ETM+ images to take an image of the EjisuJuaben district, the study area (Figure $1 \& 2$ ). A topographic map of scale 1: 25000 and road maps were obtained and used in the course of field work for direction-finding and gathering of ground control points for geo-referencing, classification and assessment of 2010 classified map. Additional secondary ground 
truth data of field points collected in 2006 in the study area by Asubonteng \& District (2007) was used for the authentication of the 2002 classification. ERDAS imagine version 2010 was used for image processing, image classification and precision assessment. ArcGIS10 was depended on for GIS operations and Excel software was used for statistical analysis. Also, Global Positioning system (GPS) instrument (Garmin 12) was used for field navigation and collection of ground truth data.

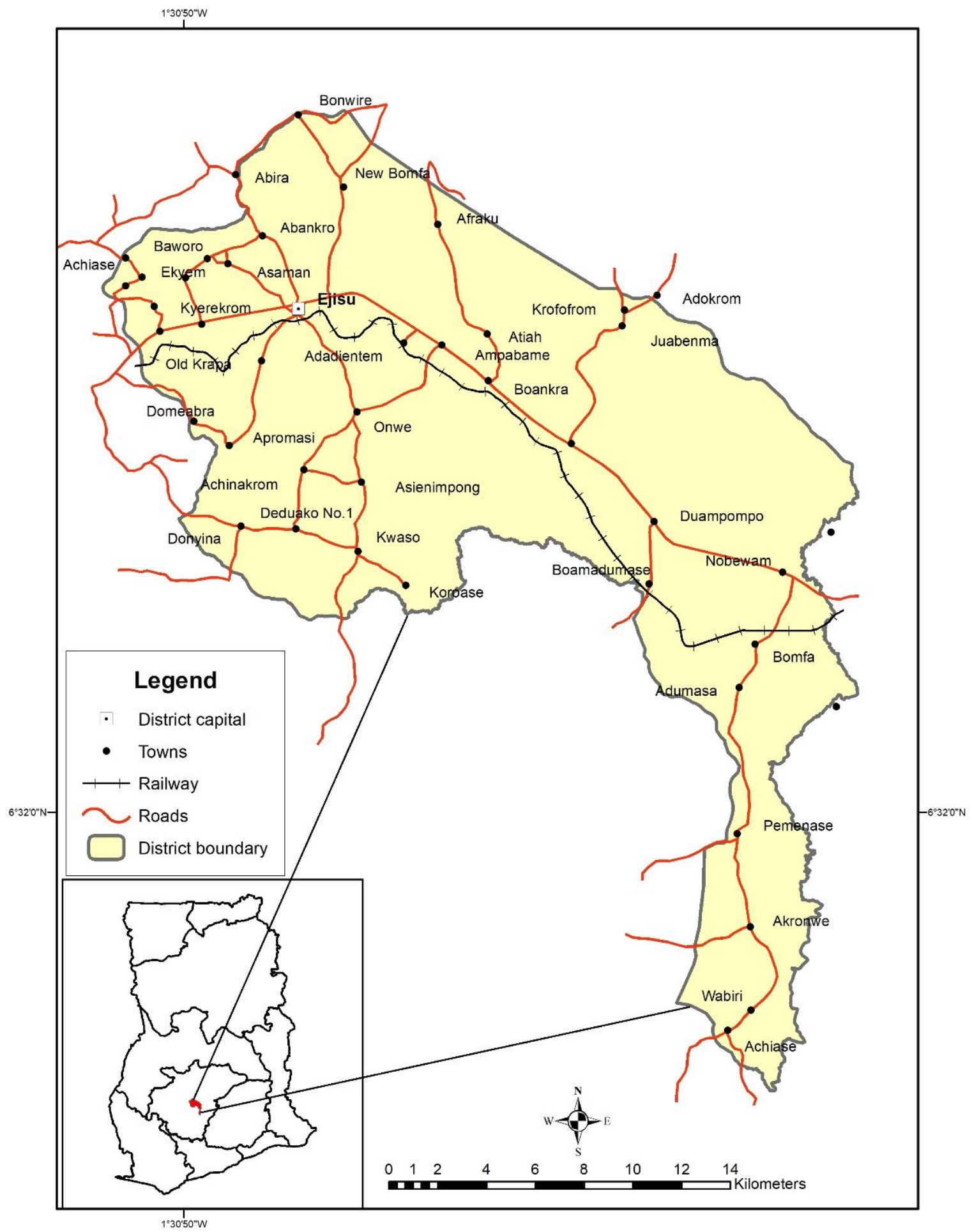

Figure 1: Map of Ejisu-Juaben District (the Study area) 
In addition to this, interviews were held with some members of the communities in the district to acertain the causes of land cover change and its impact on livelihoods.

\section{Results and Discussions}

\section{Land cover classification}

The satellite images after acquisition were processed using by first presenting a false color composite for visual interpretation. An unsupervised classification was performed using 10 categories and later reduced to five. The images were later smoothened with $5 \times 5$ filter kernel. Areas covered by the five categories of the canopy structures were calculated.

There were six (6) land cover classes identified: forest, farmland, fallow, grass and marshy area including cloud cover (mainly found in the land cover map of 2002). It was deduced that agriculture and fallow spreads across the entire study area in both maps while built-up/bare areas were predominantly pronounced in the south western portion in both maps (Figure 2). If the land cover change becomes extensive, it can have significant effect on key earth system functioning.

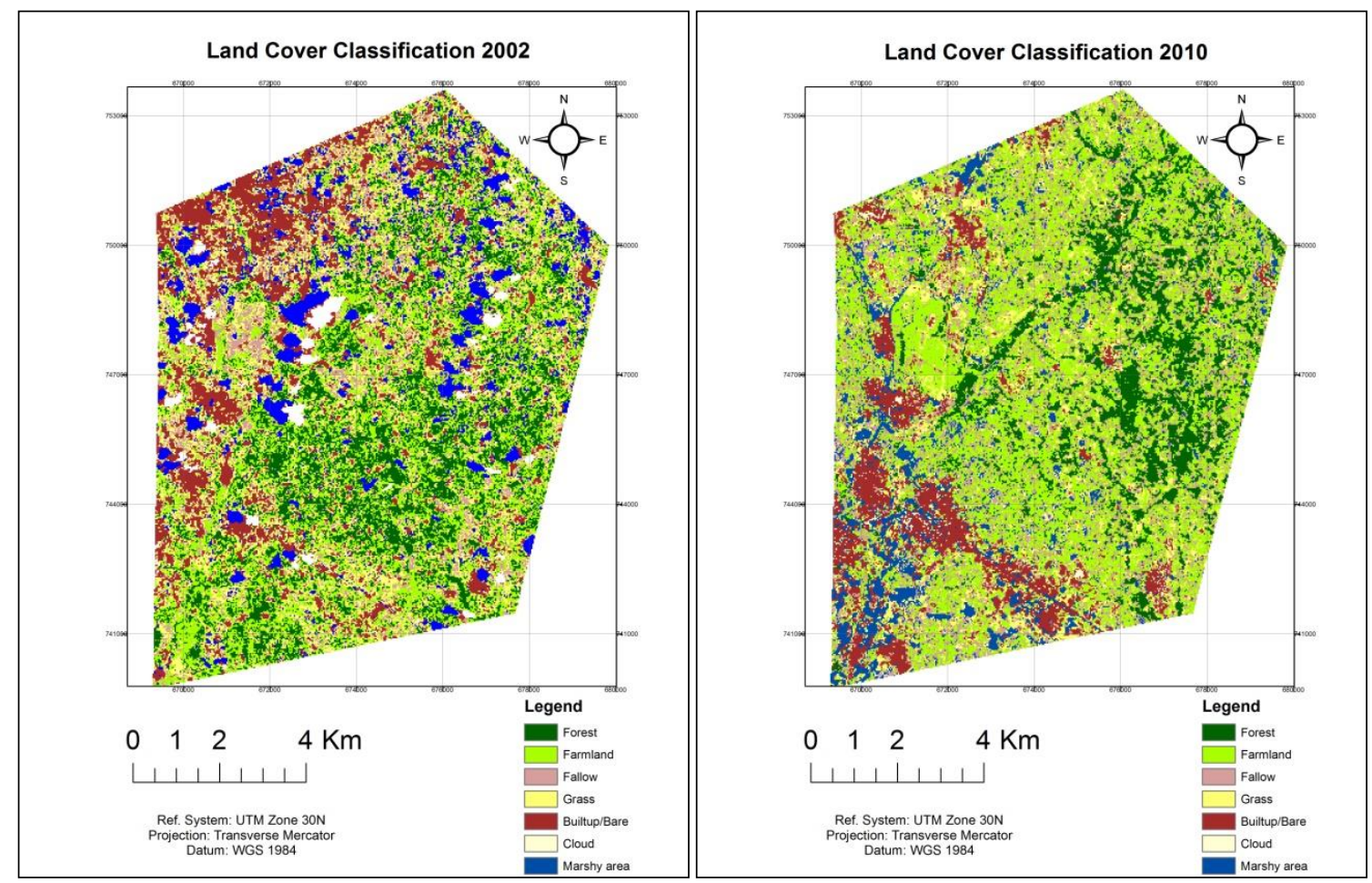

Figure 2: Land cover map of 2002 and 2010 of Ejisu-Juaben districts

\section{Accuracy Assessments}

The accuracy of the classified Landsat ETM+ images were assessed using 65 training points for the 2010 image and 54 training points for the 2002 image. The accuracy assessments for both images are shown in Tables 1 and 2. The producer's accuracies represents the probability of a point in the field being correctly classified whilst the user accuracies shows the probability of a random point on the map being correctly classified. In general, the class 'forest' and 'built up/bare' have the highest producer accuracies while the class 'built-up/bare and 'Marshy area' have the highest user's accuracies for 2010. 
Similarly, the class 'built-up/bare' has the highest producer accuracies while the class 'Marshy area' has the highest user's accuracies for 2002. The overall accuracies achieved were $84.6 \%$ and $70.3 \%$ for 2010 and 2002 images respectively.

Table 1: Accuracy Assessment for 2010 image

\begin{tabular}{|c|c|c|c|c|c|c|}
\hline \multicolumn{7}{|c|}{ Accuracy results 2010} \\
\hline Class name & $\begin{array}{l}\text { Referenc } \\
\text { e Totals }\end{array}$ & $\begin{array}{l}\text { Classified } \\
\text { Totals }\end{array}$ & $\begin{array}{l}\text { Number } \\
\text { correct }\end{array}$ & $\begin{array}{l}\text { Producer } \\
\text { Accuracy }\end{array}$ & $\begin{array}{l}\text { User } \\
\text { Accuracy }\end{array}$ & Kappa \\
\hline Forest & 18 & 19 & 18 & $100 \%$ & $94.74 \%$ & 0.93 \\
\hline Farmland & 12 & 17 & 10 & $83.33 \%$ & $58.82 \%$ & 0.50 \\
\hline Fallow & 8 & 3 & 2 & $25 \%$ & $66.67 \%$ & 0.62 \\
\hline Grass & 5 & 5 & 4 & $80 \%$ & $80 \%$ & 0.78 \\
\hline Marshy area & 5 & 4 & 4 & $80 \%$ & $100 \%$ & 1.00 \\
\hline Built-up/Bare & 16 & 16 & 16 & $100 \%$ & $100 \%$ & 1.00 \\
\hline Cloud & 1 & 1 & 1 & $100 \%$ & $100 \%$ & 1.00 \\
\hline Total & 65 & 65 & 55 & & & \\
\hline $\begin{array}{l}\text { Overall } \\
\text { Accuracy }\end{array}$ & $84.62 \%$ & & & & & \\
\hline Overall Kappa & 0.81 & & & & & \\
\hline
\end{tabular}

Table 2: Accurate Assessment for 2002

\begin{tabular}{|c|c|c|c|c|c|c|}
\hline \multicolumn{7}{|c|}{ Accuracy totals (2002) } \\
\hline Class name & $\begin{array}{l}\text { Referenc } \\
\text { e Totals }\end{array}$ & $\begin{array}{l}\text { Classified } \\
\text { Totals }\end{array}$ & $\begin{array}{l}\text { Number } \\
\text { correct }\end{array}$ & $\begin{array}{l}\text { Producer } \\
\text { Accuracy }\end{array}$ & $\begin{array}{l}\text { User } \\
\text { Accuracy }\end{array}$ & Kappa \\
\hline Forest & 19 & 14 & 11 & 57.89 & $78.57 \%$ & 0.67 \\
\hline Farmland & 13 & 19 & 12 & $92.31 \%$ & $63.16 \%$ & 0.51 \\
\hline Fallow & 3 & 4 & 3 & $100 \%$ & $75.00 \%$ & 0.74 \\
\hline Grass & 8 & 6 & 3 & 37.50 & $50.00 \%$ & 0.41 \\
\hline Marshy area & 4 & 2 & 2 & $50 \%$ & $100 \%$ & 1.00 \\
\hline Built-up/Bare & 7 & 8 & 7 & $100 \%$ & $87.50 \%$ & 0.86 \\
\hline Cloud & 0 & 1 & 0 & - & - & 0.00 \\
\hline Totals & 54 & 54 & 38 & & & \\
\hline $\begin{array}{l}\text { Overall } \\
\text { Accuracy }\end{array}$ & $70.37 \%$ & & & & & \\
\hline Overall Kappa & 0.62 & & & & & \\
\hline
\end{tabular}

\section{Change detection (2002-2010)}

Comparing the two different image dates, different levels of changes in the cover types as a result of conversions between the various cover types in the study area have been demonstrated. Table 3 shows that all the 6 land cover classes have experienced changes in size from 2002 to 2010. With regards to forest loss as shown in the land cover conversion matrix (Table 3), 819.9 ha of forest has been transferred to farmland, 417.15 ha of forest has been converted to fallow land, forest loss to Grassland was 138.51 ha, forest loss to built-up/bare land was 76.32 ha, forest loss to marshy area was 121.05 ha whilst only 425.98 ha remained unchanged. Generally, forest area has decreased by 1480.59 ha and remaining forest is 525.33 ha (representing 26.19\%). In other words, out of a forest area of 2005.92 ha in the year 2002 an area of $1,480.59$ ha has been transformed to various land use types. This is comparable to a similar study conducted in Jiangsu Province in China by Xindon et al., (2014) who showed that there was a substantial transformation in land use and land cover. The change was principally accredited to a unceasing built-up land development primarily at the expense of cropland, forest and other natural areas. This could be dangerous as land cover change can result into devastating changes in biological diversity (Sala et al., 2000); climatic systems (Chase et al., 1999; Houghton et al, 1999), soil degradation (Tolba et al., 1992 as well as human health, social, economic and political lives (Kasperson et al., 1995) 
Bare areas as a result of illegal logging, bush fire and farming after a period of time could be transferred to forest, farmland, fallow and grass (Boakye, Gils, Jr, \& Asare, 2012). For example, such abandoned bare areas within forest areas are sometimes overtaken by forest canopy in later stages. Also, bare areas due to bush fires at different stages could be transferred to forest (through plantation development), farmland, grass (for purposes of grazing) and fallow. Furthermore, 2703.51 ha of farmland has increased to 4148.3 representing $53.46 \%$; 1087.11 ha of fallow lands has increased drastically to 2214.09 ha representing $103.67 \%, 2200.05$ ha of Grassland has decreased to 956.7 representing 56.51\%, 1030.41 ha of Marshy area has decreased 935.91 representing 35.41\%, 1630.44 ha of built-up/bare area has decreased to 1053.18 representing $94.66 \%$ (Table 3).

Table 3: Land-cover class of the study area for the year 2002 and 2010

\begin{tabular}{lllll}
\hline Land cover & 2002 & 2010 & $\begin{array}{l}\text { Difference } \\
\text { Area }\end{array}$ & $+/-(\%)$ \\
\hline Forest & 2005.92 & 1480.59 & -525.33 & -26.19 \\
\hline Farmland & 2703.51 & 4148.73 & 1445.22 & 53.46 \\
\hline Fallow & 1087.11 & 2214.09 & 1126.98 & 103.67 \\
\hline Grass & 2200.05 & 956.70 & -1243.35 & -56.51 \\
\hline Marshy area & 1030.41 & 935.91 & -94.50 & -35.41 \\
\hline Built-up/Bare & 1630.44 & 1053.18 & -577.26 & -94.66 \\
\hline
\end{tabular}

It was again observed from the Land cover conversion matrix (Table 4) that, the amount of forest left was 425.98 ha, Farmland left was 1061.73 ha, Fallow land left was 224.91, Grassland left was 224.91 ha, Marshy area left was 94.5 ha whiles built-up/bare left was 415.8 ha. A similar trend was found at Buabeng-Fiema monkey sanctuary in Ghana, where the forest cover has reduced from $31.3 \%$ to $22.4 \%$ while the built-up area and agricultural fields have expanded from $47.8 \%$ to 54.5\% from 1986 to 2002, about 21years (Allotey and Wiafe, 2015).

The accelerated rate of land cover change in developing nations leaves much to be desired especially in developing nations and the common trend has been a negative impact of development on natural ecosystem. This means as the built-up areas increases, the forest areas decreases. Grossman and Krueger (1991) has described how environmental degradation indicators are related to national income and concluded that some environmental indicators, such as sulfur dioxide and suspended particulate, improved as incomes and levels of consumption went up. Degradation of natural resources has been attributed to land shortage, land tenure and open resources, economic pressures and attitudes, poverty and population increase (FAO, UNDP and UNEP 1994).

The land cover from forest to other land-use types was found to be very drastic over the eight year period (2002-2010) as the remaining forest was only about 26\% of 2002 figure of 2005.92 ha. This change can be attributed to the following observations:

1. Indiscriminate forest exploitation for forest resources such as timber and other non-timber forest products. Fuelwood harvesting was singled out as a major product affecting the conversion of forest in the district. This confirmed the report by Watson et al. (1998) that Ghana's per capita fuelwood consumption was one of the world's highest and was increasing at a very fast rate that was estimated that fuelwood harvest is approximately 12 times the volume of timber logs harvested per year.

2. Unsustainable farming practices were also identified to be one of the factors accelerating the forest loss. These include bush fallowing, slash and burn agriculture, cultivation of cash crops e.g., palm plantation.

3. The issue of urban dwellers commuting to peri-urban areas to convert the forest land to farms were paramount to contribute forest cover reduction. Since the study area is closer to Kumasi Metropolitan Assembly, many people live in the city but move occasionally to cultivate farms in the district. 
Table 4: Land cover conversion matrix

\begin{tabular}{llllllll}
\hline $\begin{array}{l}\text { Land cover } \\
\text { type }\end{array}$ & Forest & Farmland & Fallow & Grass & $\begin{array}{l}\text { Marshy } \\
\text { area }\end{array}$ & $\begin{array}{l}\text { Built- } \\
\text { up/bare }\end{array}$ & Cloud \\
\hline Forest & $\mathbf{4 2 5 . 9 8}$ & 819.90 & 417.15 & 138.51 & 121.05 & 76.32 & 8.01 \\
Farmland & 474.48 & $\mathbf{1 0 6 1 . 7 3}$ & 572.13 & 210.87 & 212.67 & 161.82 & 9.81 \\
Fallow & 107.73 & 451.17 & $\mathbf{2 2 4 . 9 1}$ & 118.62 & 85.32 & 94.41 & 4.95 \\
Grass & 192.51 & 847.17 & 469.26 & $\mathbf{2 2 4 . 9 1}$ & 229.84 & 223.74 & 12.6 \\
Marshy area & 167.58 & 442.19 & 216.09 & 67.86 & $\mathbf{9 4 . 5}$ & 53.46 & 8.73 \\
Built-up/bare & $81.45^{*}$ & $467.01 *$ & $275.58^{*}$ & $180.27 *$ & $171.09 *$ & $\mathbf{4 1 5 . 8}$ & $39.24 * *$ \\
Cloud & $31.86^{* *}$ & $79.56^{* *}$ & $38.97 * *$ & $16.66^{* *}$ & $21.42^{* *}$ & $27.63 * *$ & $\mathbf{2 . 7 0}$ \\
\hline
\end{tabular}

Note: '*' Bare areas converted due to illegal logging, bush fires. '**' unrealistic values recorded due to error in the image data used.

\section{Conclusions and Recommendations}

The following conclusions were made from the result of the study:

Firstly, within a decade, about $74 \%$ of a forest area has been converted into other non-forest landuse type such as farmlands and residential areas. This has resulted into reduction in the supply of provisioning ecosystem services and subsequently affecting the livelihoods of the inhabitants depending on it.

Secondly, the major causes to land-cover change were identified to be indiscriminate forest resources utilization, unsustainable farming practices and urban to peri-urban migration.

Recommendations made were as follows: (1) that land cover change studies should be conducted in areas or districts the urban centers (2) massive re-afforestation programmes must be intensified in peri-urban areas and (3) agroforestry must be advocated for as a sustainable land use practice.

\section{References}

Allotey, A. N. M. and Wiafe, E. D. (2015). Effect of landuse dynamics on habitat of two sympatric primates in Boabeng-Fiema Monkey Sanctuary, Ghana. Ghana Journal of Science, 55, 3-14.

Antwi, E. K., Boakye-danquah, J., Asabere, S. B., Yiran, G. A. B., Loh, S. K., Awere, K. G., ... Owusu, A. B. (2014). Land Use and Landscape Structural Changes in the Ecoregions of Ghana, 9(4), 452-453.

Asubonteng, K. O.. (2007). Identification of land use / cover transfer hotspots in the Ejisu-Juabeng District. MSc. thesis. International Institute for Geo-Informatics and Earth information, Netherlands/Kwame Nkrumah University of Science and Technology, Ghana.

Attuah, E. M. \& Laing, E. (2001). Land cover mapping of Densu basin, Ghana: Interpretations from multi-spectral imagery. Bulletin of Ghana Geography Association, 33, 1-8.

Armah, F. A., Odoi, J.O., Yengoh, G.T., Obiri, S. Yawson, D.O. \& Afrifa, E.K. (2011). Food security and climate change in drought sensitive savanna zones in Ghana. Mitigation and adaptive strategies for global change, 16, 291-306.

Boakye, E. A., Gils, H. Van, Jr, E. M. O., \& Asare, V. N. A. (2012). Does forest restoration using taungya foster tree species diversity? The case of Afram Headwaters Forest Reserve in Ghana. African Journal of Ecology, $50,319-325$.

Briassoulis, H. (2009). Land use, land cover and soil science - Factors Influencing Land-use and Land-Cover Change. Encyclopedia of Life Support Systems (EOLSS), I, 9.

Chase, T.N., Pielke, R.A., Kittel, T.G.F., Nemani, R.R., Running, S.W., (1999). Simulated impacts of historical land cover changes on global climate in northern winter. Climate Dynamics, 16, 93-105.

Chen, X. (2002). Using remote sensing and GIS to analyse land cover change and its impact on regional sustainable development. International Journal of Remote Sensing, 23(1), 107-124. 
FAO, UNDP and UNEP (1994). Land degradation in south Asia: Its severity, causes and effects upon the people. Rome, FAO.

Kasperson, J.X., Kasperson, R.E., Turner, B.L. II (Eds.), 1995. Regions at Risk: Comparisons of Threatened Environments. United Nations Univ. Press, Tokyo.

Grossman, G.M. and Krueger, A. B. (1991). Environmental Impacts of a North American Free Trade Agreement. Working Paper 3914, National Bureau of Economic, Cambridge.

Houghton, R.A., Hackler, J.L., Lawrence, K.T., (1999). The U.S. carbon budget: contribution from land-use change. Science, 285, 574-578.

Meyer, W.B. \& Turner II, B.L. (1992). Human population growth and global landuse / cover change. Annual Review of Ecology and Systematics, 23, 39-61.

Sala, O.E., Chapin, F.S., Armesto, J.J., Berlow, E., Bloomfield, J., Dirzo, R., Huber-Sanwald, E., Huenneke, L.F., Jackson, R.B., Kinzig, A., Leemans, R., Lodge, D.M., Mooney, H.A., Oesterheld, M., Poff, N.L., Sykes, M.T., Walker, B.H., Walker, M., Wall, D.H., 2000. Biodiversity: global biodiversity scenarios for the year 2100. Science $287,1770-1774$.

Tolba, M.K., El-Kholy, O.A. (Eds.), (1992). The World Environment 1972-1992: Two Decades of Challenge. Chapman \& Hall, London.

Turner, M.G. (1989). Landscape ecology: the effect of pattern on process. Annual Review of Ecology and Systemtics, 20, 171-197.

Tutu, B. D. (2008). Assessing the effects of land-use / cover change on ecosystem services in Ejisu-Juaben District , Ghana: The case study of carbon sequestration Ejisu-Juaben District, Ghana: MSc. thesis. International Institute for Geo-Informatics and Earth information, Netherlands/Kwame Nkrumah University of Science and Technology, Ghana.

Watson, R. T., Dixon, J. A., Humburg, S. P., Janetos, A.C. \& Moss R. H. (1998). Protecting our planet, securing our future. Linkages among global environmental issues and human needs. UNEP/USNASA/The World bank.

Xindong, D., Xiaobin, J., Xilian, Y., Xuhong, Y. and Yinkang, Z. (2014). Spatial pattern of land use change and its driving force in Jiangsu Province, China. Environmental Research and Public Health, 11, 3215-3232.

Submitted: 08.07.2017 - Accepted: 07.02.2018 